\title{
PERKEMBANGAN PERBANKAN SYARIAH DI INDONESIA
}

\author{
Nofinawati \\ Fakultas Ekonomi dan Bisnis Islam IAIN Padangsidimpuan \\ Jl. T. Rizal Nurdin Km. 4,5 Sihitang, Padangsidimpuan 22733 \\ e-mail: nofinawatiseima@yahoo.com
}

\begin{abstract}
Sharia banking in Indonesia has approached 24 years of age. This age implies that it such sharia banking has shifted to maturity phase. It has developed significantly compared to that of previous years. It can be observed from its average growth of its assets, DPK, PYD which is 45\% higher than the years of 2000 up to 2014. However, it is expected that it must able to make use of opportunities which are presently available to encounter challenges in the future, Consequently, it should be able to take advantage of supports and contributions of other such related parties as government, ulama, society, academicians, and students majoring in sharia banking as well.
\end{abstract}

Kata kunci: development, sharia banking, Indonesia

\section{PENDAHULUAN}

$P$

erkembangan

syariah di Indonesia telah menjadi tolak ukur keberhasilan eksistensi ekonomi syariah. Bank Muamalat Indonesia sebagai bank syariah pertama dan menjadi pioneer bagi bank syariah lainnya, dan telah lebih dahulu menerapkan sistem ini di tengah menjamurnya bank-bank konvensional. Krisis moneter yang terjadi pada tahun 1998 telah menenggelamkan bank-bank konvensional dan banyak yang dilikuidasi karena kegagalan sistem bunganya. Sementara perbankan yang menerapkan sistem syariah dapat tetap eksis dan mampu bertahan.

Tidak hanya itu, di tengahtengah krisis keuangan global yang melanda dunia pada penghujung akhir tahun 2008, lembaga keuangan syariah kembali membuktikan daya tahannya dari terpaan krisis. Lembaga-lembaga keuangan syariah tetap stabil dan memberikan keuntungan, kenyamanan serta keamanan bagi para pemegang sahamnya, pemegang surat berharga, para nasabah pembiayaan dan para nasabah penyimpan dana di bank-bank syariah.

Hal ini dapat dibuktikan dari keberhasilan Bank Muamalat Indonesia melewati krisis yang terjadi pada tahun 1998 dengan menunjukkan kinerja yang semakin meningkat dan tidak menerima sepersen pun bantuan dari pemerintah dan pada krisis keuangan tahun 2008, Bank Muamalat Indonesia bahkan mampu memperoleh laba Rp. 300 miliar lebih. Perbankan syariah sebenarnya dapat menggunakan momentum ini untuk menunjukkan bahwa perbankan syariah benar-benar 
tahan dan kebal krisis dan mampu tumbuh dengan signifikan.

\section{PRAKTIK PERBANKAN DI ZAMAN RASULULLAH SAW}

Secara umum, bank adalah lembaga yang melaksanakan tiga fungsi utama yaitu menghimpun dana, menyalurkan dana, melayani jasa keuangan lainnya. Ketiga fungsi utama tersebut merupakan fungsi utama dari bank konvensional yang menggunakan sistem bunga (riba) dalam kegiatan operasionalnya. Namun bank syariah memiliki empat fungsi dalam kegiatan operasionalnya. Selain dari ketiga fungsi utama di atas, satu fungsi utama lainnya yang ada pada bank syariah adalah fungsi sosial dalam bentuk kegiatan penghimpunan dan penyaluran dana zakat, infak dan sedekah serta penyaluran dana dalam bentuk pinjaman kebajikan (qardul hasan).

Di dalam sejarah perekonomian umat Islam, pembiayaan yang dilakukan dengan akad yang sesuai syariah telah menjadi bagian dari tradisi umat Islam sejak zaman Rasulullah SAW. Praktik-praktik seperti menerima titipan harta, meminjamkan uang untuk keperluan konsumsi dan untuk keperluan bisnis, serta melakukan pengiriman uang telah lazim dilakukan sejak zaman Rasulullah SAW. Dengan demikian, fungsi-fungsi utama perbankan modern, yaitu menerima deposit atau simpanan, menyalurkan dana dan melakukan transfer dana telah menjadi bagian yang tidak terpisahkan dari kehidupan umat
Islam, bahkan sejak zaman Rasulullah SAW (Adiwarman A. Karim, 2007: 18).

Praktik-praktik dari fungsi perbankan tersebut masih dilakukan oleh individu-individu. Contohnya: Rasulullah SAW dan Khadijah pernah mempraktikkan akad mudharabah semasa hidup mereka. Khadijah bertindak sebagai shahibul maal dan Rasulullah SAW bertindak sebagai mudharib (pengelola dana). Dana tersebut dikelola oleh Rasulullah SAW dalam bentuk usaha perdagangan. Setelah Rasulullah SAW memperoleh hasil dari usahanya, maka Rasulullah akan memberikan bagi hasil kepada Khadijah sesuai dengan kesepakatan mereka di awal akad. Dengan demikian dapat dipahami bahwa lembaga perbankan belum ada pada masa Rasullah SAW, namun praktik perbankan secara individu telah menjadi tradisi umat Islam.

\section{SEJARAH BERDIRINYA BANK SYARIAH}

Gagasan mengenai bank yang menggunakan sistem bagi hasil telah muncul sejak lama, ditandai dengan banyaknya pemikir-pemikir muslim yang menulis tentang keberadaan bank syariah, misalnya Anwar Qureshi (1946), Naiem Siddiqi (1948), dan Mahmud Ahmad (1952). Kemudian uraian yang lebih terperinci tentang gagasan itu ditulis oleh Mawdudi (1961). Demikian juga dengan tulisan-tulisan Muhammad Hamidullah yang ditulis pada 1944, 1955, 1957, dan 1962, bisa dikategorikan sebagai gagasan 
pendahulu mengenai perbankan Islam (Heri Sudarsono, 2007: 28).

Perbankan yang mulanya hanya ada di daratan Eropa kemudian menyebar ke Asia Barat. Sejalan dengan perkembangan daerah jajahan, maka perbankan pun ikut dibawa ke negara jajahan mereka. Di Indonesia juga tidak terlepas dari penjajahan Belanda yang mendirikan beberapa bank seperti De Javasche Bank, De Post Paar Bank dan lainnya serta bank-bank milik pribumi, Cina, Jepang, dan Eropa seperti Bank Nasional Indonesia, Batavia Bank, dan Iainnya. Di zaman kemerdekaan perbankan Indonesia sudah semakin maju, mulai dari bank pemerintah maupun bank swasta (Andri Soemitra, 2009: 62).

Sejarah perkembangan bank syariah modern tercatat di Pakistan dan Malaysia sekitar tahun 1940, yaitu upaya pengelolaan dana jamaah haji secara nonkonvensional. Rintisan bank syariah lainnya adalah dengan berdirinya Mit Ghamr Lokal Saving Bank pada tahun 1963 di Mesir oleh Dr. Ahmad el-Najar. Secara kolektif gagasan berdirinya bank syariah di tingkat internasional, muncul dalam konferensi negara-negara Islam sedunia, di Kuala Lumpur, Malaysia pada tanggal 21-27 April 1969, yang diikuti oleh 19 negara peserta. Konferensi tersebut memutuskan beberapa hal, yaitu: (Heri Sudarsono, 2007: 28 )

1. Tiap keuntungan haruslah tunduk kepada hukum untung dan rugi, jika tidak ia termasuk riba dan riba itu sedikit atau banyak hukumnya haram.

2. Diusulkan supaya dibentuk suatu bank syariah yang bersih dari sistem riba dalam waktu secepat mungkin.

3. Sementara menunggu berdirinya bank syariah, bank-bank yang menerapkan bunga diperbolehkan beroperasi. Namun jika benar-benar dalam keadaan darurat.

Pembentukan bank syariah semula memang banyak diragukan, sebab:

1. Banyak yang beranggapan bahwa sistem perbankan bebas bunga (interest free) adalah suatu yang tak mungkin dan tidak lazim.

2. Adanya pertanyaan tentang bagaimana bank akan membiayai operasinya. Tetapi di lain pihak, bank Islam adalah satu alternatif sistem ekonomi Islam.

Untuk lebih mempermudah berkembangnya bank syariah di negara-negara muslim perlu ada usaha bersama di antara negara muslim. Maka pada bulan Desember 1970, pada Sidang Menteri Luar Negeri negara-negara Organisasi Konferensi Islam (OKI) di Karachi, Pakistan, delegasi Mesir mengajukan sebuah proposal untuk mendirikan bank syariah. Proposal tentang Pendirian Bank Islam Internasional untuk Perdagangan dan Pembangunan (International Islamic Bank for Trade and Development) dan proposal pendirian Federasi Bank Islam (Federation of Islamic Bank) dikaji para ahli dari delapan belas negara Islam. 
Pada Sidang Menteri Luar Negeri OKI di Benghazi, Libya, Maret 1973 usulan tersebut kembali diagendakan. Sidang kemudian memutuskan agar OKI mempunyai bidang yang khusus menangani masalah ekonomi dan keuangan. Bulan Juli 1973, komite ahli yang mewakili negara-negara Islam penghasil minyak bertemu di Jeddah, Arab Saudi untuk membicarakan pendirian bank syariah. Rancangan pendirian bank tersebut, berupa anggaran dasar dan anggaran rumah tangga, dibahas pada pertemuan kedua, Mei 1974. Pada sidang Menteri Keuangan OKI di Jeddah, 1974, disetujui rancangan pendirian Bank Pembangunan Islam atau Islamic Development Bank (IDB) dengan modal 12 miliar dinar atau ekuivalen 2 miliar SDR (special drawing right) IMF (International Monetary Fund).

Berdirinya IDB memotivasi negara-negara Islam untuk mendirikan lembaga keuangan syariah. Pada akhir periode 1970-an dan awal dekade 1980-an, lembaga keuangan syariah bermunculan di Mesir, Sudan, negara-negara Teluk, Pakistan, Iran, Malaysia, serta Turki termasuk Indonesia pada periode 1990-an (M. Ridwan, 2004: 69). Selain itu, ada negara-negara non-muslim yang mendirikan bank Islam, seperti Inggris, Denmark, Bahamas (Benon), Swiss, dan Luxemburg. Secara garis besar, lembaga-lembaga keuangan syariah tersebut dimasukkan dalam dua kategori, yaitu bank Islam komersial (Islamic Comersial Bank) dan lembaga investasi dalam bentuk
International Holding Companies (M. Syafi'i Antonio, 1999: 232).

Pesatnya perkembangan bank syariah menimbulkan ketertarikan bank konvensional untuk menawarkan produk-produk bank syariah. Hal tersebut tercermin dari tindakan beberapa bank konvensional yang membuka sistem tertentu di dalam masing-masing bank dalam menawarkan produk bank syariah, misalnya "Islamic windows" di Malaysia, "the Islamic transactions" di cabang Bank Mesir, dan "the Islamic services" di cabangcabang bank perdagangan Arab Saudi. Sementara itu Citibank mendirikan Citi Islamic Investment Bank pada tahun 1996 di Bahrain yang merupakan wholly-owned subsidiary.

\section{PERKEMBANGAN BANK SYARIAH DI INDONESIA}

Gagasan untuk mendirikan bank syariah di Indonesia sebenarnya sudah muncul sejak pertengahan tahun 1970-an. Hal ini dibicarakan pada seminar nasional Hubungan Indonesia-Timur Tengah pada 1974 dan pada tahun 1976 dalam seminar internasional yang diselenggarakan oleh Lembaga Studi Ilmu-Ilmu Kemasyarakatan (LSIK) dan Yayasan Bhineka Tunggal Ika. Namun, ada beberapa alasan yang menghambat terealisasinya ide ini:

1. Operasi bank syariah yang menerapkan prinsip bagi hasil belum diatur, dan karena itu, tidak sejalan dengan UU Pokok Perbankan yang berlaku, yakni UU No 14/1967. 
2. Konsep bank syariah dari segi politis berkonotasi ideologis, merupakan bagian dari atau berkaitan dengan konsep negara Islam, dan karena itu tidak dikehendaki pemerintah.

3. Masih dipertanyakan, siapa yang bersedia menaruh modal dalam ventura semacam itu, sementara pendirian bank baru dari Timur Tengah masih dicegah, antara lain pembatasan bank asing yang ingin membuka kantornya di Indonesia.

Akhirnya gagasan mengenai bank syariah itu muncul lagi sejak tahun 1988, di saat pemerintah mengeluarkan Paket Kebijakan Oktober (Pakto) yang berisi liberalisasi industri perbankan. Para ulama pada waktu itu berusaha untuk mendirikan bank bebas bunga, tapi tidak ada satupun perangkat hukum yang dapat dirujuk, kecuali bahwa perbankan dapat saja menetapkan bunga sebesar $0 \%$. Setelah adanya rekomendasi dari lokakarya ulama tentang bunga bank dan perbankan di Cisarua, Bogor tanggal 19-22 Agustus 1990, yang kemudian dibahas lebih mendalam pada Musyawarah Nasional (Munas) IV Majelis Ulama Indonesia (MUI) yang berlangsung di Hotel Sahid Jaya, Jakarta, 22-25 Agustus 1990, dibentuklah kelompok kerja untuk mendirikan bank syariah di Indonesia (Frianto Pandia, 2005: 189 ).

Bank Muamalat Indonesia adalah bank syariah pertama di Indonesia yang lahir sebelum lahirnya Undang-undang Nomor 7 tahun 1992 yang memungkinkan berdirinya bank yang sepenuhnya melakukan kegiatan berdasarkan prinsip syariah (Sutan Remy Syahdeini, 2014: 97) BMI lahir sebagai hasil kerja tim Perbankan MUI tersebut di atas. Akte pendirian PT Bank Muamalat Indonesia ditandatangani pada tanggal 1 November 1991. Pada saat akte pendirian ini terkumpul komitmen pembelian saham sebanyak Rp. 84 miliar. Pada tanggal 3 Nopember 1991, dalam acara silaturahmi Presiden di Istana Bogor, dapat dipenuhi dengan total komitmen modal disetor awal sebesar Rp. 106.126.382.000,-. Dana tersebut berasal dari presiden dan wakil presiden, sepuluh menteri Kabinet Pembangunan V, juga Yayasan Amal Bakti Muslim Pancasila, Yayasan Dakab, Supersemar, Dharmais, Purna Bhakti Pertiwi, PT PAL, dan PT Pindad. Selanjutnya, Yayasan Dana Dakwah Pembangunan ditetapkan sebagai yayasan penopang bank syariah. Dengan terkumpulnya modal awal tersebut, pada tanggal 1 Mei 1992, Bank Muamalat Indonesia (BMI) mulai beroperasi.

Keberadaan BMI ini semakin diperkuat secara konstitusi dengan munculnya Undang-Undang (UU) No. 7 tahun 1992 tentang Perbankan, di mana perbankan bagi hasil diakomodasi. Dalam UU tersebut, pasal 13 ayat (c) menyatakan bahwa salah satu usaha Bank Perkreditan Rakyat (BPR) menyediakan Pembiayaan bagi nasabah berdasarkan prinsip bagi hasil sesuai dengan ketentuan yang ditetapkan 
dalam peraturan pemerintah. Menanggapi Pasal tersebut, pemerintah pada tanggal 30 Oktober 1992 telah mengeluarkan Peraturan Pemerintah (PP) No. 72 tahun 1992 tentang bank berdasarkan prinsip bagi hasil dan diundangkan pada tanggal 30 Oktober 1992 dalam lembaran negara Republik Indonesia No. 119 tahun 1992 (Syukri Iska, 2012: 253)

Pendirian Bank Muamalat ini diikuti oleh Bank Perkreditan Rakyat Syariah (BPRS). Namun demikian, keberadaan dua jenis lembaga keuangan tersebut belum sanggup menjangkau masyarakat Islam lapisan bawah. Oleh karena itu, dibentuklah lembaga-lembaga keuangan mikro syariah yang disebut Baitul Maal Wattamwil (BMT). Setelah dua tahun beroperasi, Bank Muamalat mensponsori berdirinya asuransi Islam, Syarikat Takaful Indonesia (STI) dan menjadi salah satu pemegang sahamnya. Tiga tahun kemudian, yaitu 1997, Bank Muamalat mensponsori lokakarya ulama tentang reksadana syariah yang kemudian diikuti dengan beroperasinya Reksadana Syariah oleh PT Danareksa Investment Management.

Pada tahun 1998 muncul UU No. 10 tahun 1998 tentang perubahan UU No. 7 tahun 1992 tentang Perbankan. Dalam UU ini terdapat beberapa perubahan yang memberikan peluang yang lebih besar bagi pengembangan perbankan syariah. Dari UU tersebut disebutkan bahwa sistem perbankan syariah dikembangkan dengan tujuan:
1. Memenuhi kebutuhan jasa perbankan bagi masyarakat yang tidak menerima konsep bunga. Dengan ditetapkannya sistem perbankan syariah yang berdampingan dengan sistem perbankan konvensional, mobilitas dana masyarakat dapat dilakukan secara lebih luas terutama dari segmen yang selama ini belum dapat tersentuh oleh sistem perbankan konvensional yang menerapkan sistem bunga.

2. Membuka peluang pembiayaan bagi pengembangan usaha berdasarkan prinsip kemitraan. Dalam prinsip ini, konsep yang diterapkan adalah hubungan investor yang harmonis (mutual investor relationship). Sementara, dalam bank konvensional konsep yang diterapkan adalah hubungan debitur dan kreditur (debitor to creditor relationship).

3. Memenuhi kebutuhan akan produk dan jasa perbankan yang memiliki beberapa keunggulan komparatif berupa peniadaan pembebanan bunga yang berkesinambungan (perpectual interest effect) membatasi kegiatan spekulasi yang tidak produktif (unproductive speculation), pembiayaan ditujukan kepada usaha-usaha yang lebih mcmperhatikan unsur moral.

Pemberlakuan UU No. 10 tahun 1998 tentang perubahan UU No. 7 tahun 1992 tentang Perbankan yang diikuti dengan dikeluarkannya sejumlah ketentuan pelaksanaan dalam bentuk SK Direksi BI/ Peraturan Bank Indonesia, telah 
memberikan landasan hukum yang lebih kuat bagi pengembangan perbankan syariah di Indonesia. Peraturan-peraturan tersebut memberikan kesempatan yang luas untuk mengembangkan jaringan perbankan syariah antara lain melalui izin pembukaan Kantor Cabang Syariah (KCS) oleh bank konvensional. Dengan kata lain, bank umum dapat menjalankan dua kegiatan usaha, baik secara konvensional maupun berdasarkan prinsip syariah (Heri Sudarsono, 2007: 30-34).

Pada tanggal 16 Juli 2008, UU No. 21 Tahun 2008 tentang Perbankan Syariah disahkan yang memberikan landasan hukum industri perbankan syariah nasional dan diharapkan mendorong perkembangan bank syariah yang selama lima tahun terakhir asetnya tumbuh lebih dari ( $>5 \%$ per tahun namun pasarnya (market share) secara nasional masih di bawah 5\%. Undang-undang ini mengatur secara khusus mengenai perbankan syariah, baik secara kelembagaan maupun kegiatan usaha. Beberapa lembaga hukum baru diperkenalkan dalam UU No. 21 Tahun 2008, antara lain yakni menyangkut pemisahan (spin-off) UUS baik secara sukarela maupun wajib dan Komite Perbankan Syariah (Undang-undang Nomor 21 tahun 2008 tentang Perbankan Syariah, 2008).

Selain itu terdapat beberapa PBI yang diamanahkan oleh UU No. 21/ 2008. Adapun PBI yang secara khusus merupakan peraturan pelaksana dari Undang-Undang Nomor 21 Tahun 2008 tentang
Perbankan Syariah dan telah diundangkan hingga saat ini antara lain:

1. PBI No.10/16/PBI/2008 tentang Perubahan Atas PBI No. 9/19/PBI/2007 tentang Pelaksanaan Prinsip Syariah dalam Kegiatan Penghimpunan Dana dan Penyaluran Dana serta Pelayanan Jasa Bank Syariah.

2. PBI No.10/17/PBI/2008 tentang Produk Bank Syariah dan Unit Usaha Syariah.

3. PBI No.10/18/PBI/2008 tentang Restrukturisasi Pembiayaan Bank Syariah.

4. PBI No.10/23/PBI/2008 tentang Perubahan Kedua Atas PBI No. 6/21/PBI/2004 tentang Giro Wajib Minimum dalam Rupiah dan Valuta Asing bagi Bank Umum yang Melaksanakan Kegiatan Usaha Berdasarkan Prinsip Syariah.

5. PBI No.10/24/PBI/2008 tentang Perubahan Kedua Atas PBI No. 8/21/PBI/ 2006 tentang Penilaian Kualitas Aktiva Bank Umum yang Melaksanakan Kegiatan Usaha Berdasarkan Prinsip Syariah.

6. PBI No. 10/32/PBI/2008 tentang Komite Perbankan Syariah.

7. PBI No. 11/3/PBI/2009 tentang Bank Umum Syariah.

Agustianto juga mengemukakan bahwa perkembangan perbankan syariah di Indonesia makin pesat dan berkembang secara fantastis. Krisis keuangan global di satu sisi telah membawa hikmah bagi perkembangan perbankan syariah. Hal ini dikarenakan masyarakat dunia, para pakar, dan pengambil 
kebijakan ekonomi, tidak saja melirik tetapi lebih dari itu mereka ingin menerapkan konsep syariah ini secara serius (Agustianto, http://www.pelita.or.id, akses 07 Desember 2015).

Di Indonesia prospek perbankan syariah makin cerah dan menjanjikan. Bank syariah di negeri ini, diyakini akan terus tumbuh dan berkembang di masa depan. Perbankan syariah dapat dikategorikan sebagai jenis industri baru yang mempunyai daya tarik cukup tinggi. Hal ini dapat dilihat dari banyaknya pemain baru yang bermain, tidak hanya dalam bentuk bank umum dan BPRS, tetapi juga dalam bentuk UUS (Iman Hilman, dkk., 2003: 38). Untuk lebih jelasnya, di bawah ini akan penulis paparkan perkembangan kelembagaan dan kinerja perbankan syariah di Indonesia sebagai berikut :

Tabel 1

Perkembangan Kelembagaan dan Kinerja Perbankan Syariah Indonesia

\begin{tabular}{|c|c|c|c|c|c|c|c|c|c|c|c|c|c|c|c|}
\hline Indikator & $\mathbf{2 0 0 0}$ & $\mathbf{2 0 0 1}$ & $\mathbf{2 0 0 2}$ & $\mathbf{2 0 0 3}$ & $\mathbf{2 0 0 4}$ & $\mathbf{2 0 0 5}$ & $\mathbf{2 0 0 6}$ & $\mathbf{2 0 0 7}$ & $\mathbf{2 0 0 8}$ & $\mathbf{2 0 0 9}$ & $\mathbf{2 0 1 0}$ & $\mathbf{2 0 1 1}$ & $\mathbf{2 0 1 2}$ & $\mathbf{2 0 1 3}$ & $\mathbf{2 0 1 4}$ \\
\hline BUS & 2 & 2 & 2 & 2 & 3 & 3 & 3 & 3 & 5 & 6 & 11 & 11 & 11 & 11 & 12 \\
\hline UUS & 3 & 3 & 6 & 8 & 15 & 19 & 20 & 26 & 27 & 25 & 23 & 24 & 24 & 23 & 22 \\
\hline BPRS & 79 & 81 & 83 & 84 & 88 & 92 & 105 & 114 & 131 & 138 & 150 & 155 & 158 & 163 & 163 \\
\hline Jaringan kantor & 146 & 182 & 229 & 337 & 443 & 550 & 693 & 802 & 1,069 & 1,258 & 1,763 & 2,101 & 2,663 & 2,990 & 2,910 \\
\hline Aset (miliar Rp) & 1,790 & 2,719 & 4,045 & 8,152 & 15,803 & 21,502 & 27,618 & 37,754 & 49,555 & 66,090 & 97,519 & 145,467 & 195,018 & 242,276 & 272,343 \\
\hline DPK (miliar Rp) & 1,029 & 1,806 & 2,918 & 5,910 & 12,129 & 15,933 & 21,193 & 28,730 & 36,852 & 52,271 & 76,036 & 115,415 & 147,512 & 183,534 & 217,858 \\
\hline PYD (miliar Rp) & 1,271 & 2,050 & 3,277 & 5,723 & 11,821 & 15,688 & 21,060 & 28,837 & 38,195 & 46,886 & 68,181 & 102,655 & 147,505 & 184,122 & 199,330 \\
\hline
\end{tabular}

Sumber : Data Statistik Perbankan Syariah OJK (OJK, http://www.ojk.go.id, akses 07 Desember 2015)

Perkembangan industri lembaga keuangan perbankan syariah di atas semakin menunjukkan keunggulannya dalam memperkuat stabilitas sistem keuangan nasional. Jika dilihat dari jumlah Bank Umum Syariah di Indonesia dari tahun 2000 s.d. 2014 perbankan syariah mengalami pertumbuhan pesat. Dari tahun 1992 s.d. 1999 hanya ada satu Bank Umum Syariah di Indonesia yaitu Bank Muamalat Indonesia (BMI). Kemudian dari tahun 2000 s.d. 2003 Bank Umum Syariah bertambah satu yaitu Bank Syariah Mandiri (BSM). Kemudian dari tahun 2004 s.d. 2007 Bank Umum Syariah bertambah satu lagi yaitu Bank Syariah Mega Indonesia (BSMI). Pada tahun 2008 bertambah dua Bank Umum Syariah yaitu unit Usaha Syariah yang melakukan spin-off (BRI Syariah dan Bank Syariah Bukopin), pada tahun 2009 bertambah satu lagi Bank Umum Syariah di Indonesia yaitu BNI Syariah. Pada tahun 2010 s.d. sekarang terjadi perkembangan yang pesat dengan pertambahan 6 Bank Umum Syariah di Indonesia yaitu BJB Banten Syariah, Bank Viktoria Syariah, Bank Panin Syariah, BCA Syariah, Maybank Syariah Indonesia, BTPN Syariah.

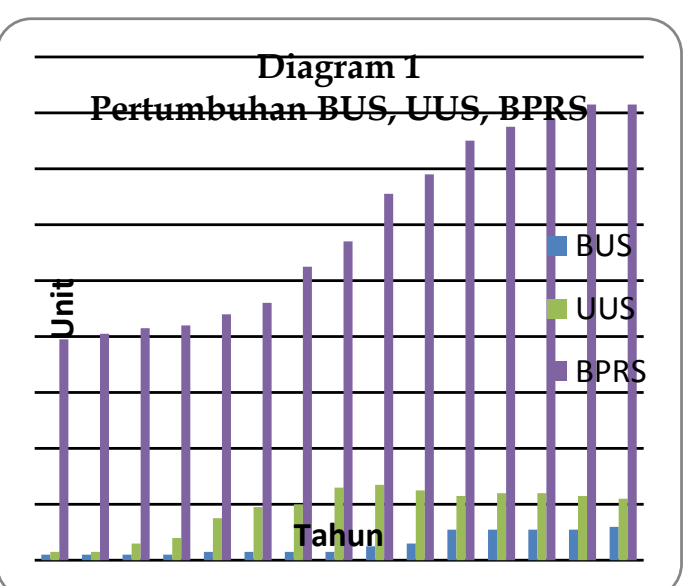


Berdasarkan diagram di atas, dapat dilihat bahwa pertumbuhan perbankan syariah dari segi lembaganya selalu mengalami peningkatan. Walaupun peningkatannya perlahan, namun pertumbuhan yang paling pesat terjadi pada tahun 2008 s.d. 2013, setelah disyahkannya UU nomor 21 tahun 2008 tentang perbankan syariah. Jika dilihat dari jumlah Unit Usaha Syariah di Indonesia dari tahun 2000 s.d. tahun 2014 perbankan syariah juga selalu mengalami peningkatan. Begitu juga dengan jumlah Bank Pembiayaan Rakyat Syariah selalu mengalami perningkatan dari tahun 2000 s.d. 2014.

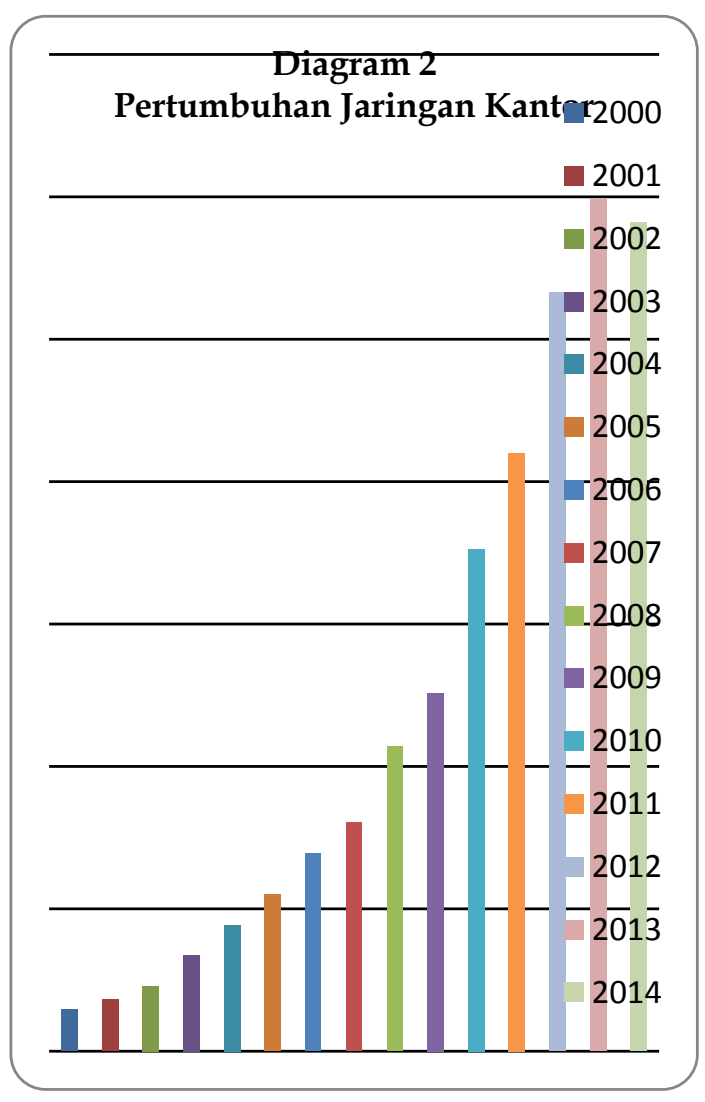

Berdasarkan diagram di atas, pertumbuhan jumlah jaringan kantor perbankan syariah dari tahun ke tahun selalu bertambah dengan pertumbuhan rata-rata $24,4 \%$, namun berfluktuasi. Seperti pertumbuhan jaringan kantor bank syariah pada tahun 2001 yaitu 24,7\%, pada tahun 2002 yaitu 25,8\%. Namun pada tahun 2003 pertumbuhannya meningkat menjadi 47,2\%. Kemudian pada tahun 2004 pertumbuhannya berkurang menjadi 31,5\%, pada tahun 2005 berkurang lagi menjadi 24,2\%. Namun pada tahun 2006 pertumbuhan bank syariah meningkat lagi menjadi 26\%. Namun pada tahun 2007 pertumbuhannya berkurang lagi menjadi 15,7\%. Pada tahun 2008 pertumbuhannya meningkat lagi menjadi 33,3\%. Namun pada tahun 2009 pertumbuhannya berkurang lagi menjadi $17,7 \%$.

Sedangkan pada tahun 2010 pertumbuhannya meningkat lagi menjadi $40,1 \%$. Namun pada tahun 2011 pertumbuhannya menurun lagi menjadi 19,2\%. Pada tahun 2012 pertumbuhan jaringan kantor meningkat lagi menjadi 26,7\%. Namun pada tahun 2013 pertumbuhannya menurun lagi menjadi $12,3 \%$. Jaringan kantor tersebut telah menjangkau masyarakat di 33 propinsi dan di hampir 100 kabupaten/kota. Namun pada tahun 2014 perkembangan perbankan syariah dari jumlah jaringan kantor mengalami penurunan $\quad 2,7 \% \quad$ dengan 
berkurangnya 80 jaringan kantor dari tahun sebelumnya.

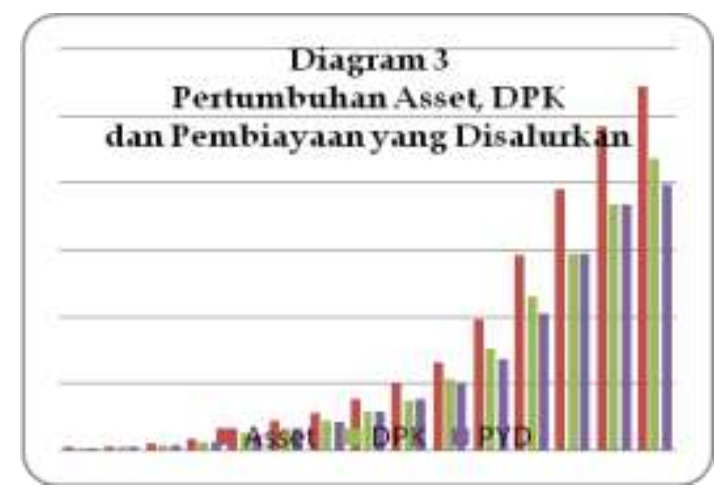

Dari aspek penghimpunan dana dan penyaluran dana, perbankan syariah di Indonesia menunjukkan kinerja yang sangat bagus. Hal itu terlihat pada data statistik perbankan syariah yang dipublikasikan oleh Otoritas Jasa Keuangan, di mana pertumbuhan jumlah asset, jumlah DPK (Dana Pihak Ketiga), dan jumlah PYD (Pembiayaan yang Disalurkan) selalu mengalami peningkatan dari tahun ke tahun.

1. Pertumbuhan Asset

Pertumbuhan asset pada tahun 2001 mencapai 51,9\% dari tahun sebelumnya. Pada tahun 2002 pertumbuhan asset mengalami penurunan menjadi 48,8\%. Kemudian pada tahun 2003 pertumbuhan asset mengalami peningkatan yang pesat menjadi $101,5 \%$ dari tahun sebelumnya. Namun pada tahun 2004 pertumbuhan asset mengalami penurunan menjadi 93,9\%. Begitu juga pada tahun 2005 dan 2006 pertumbuhan asset mengalami penurunan menjadi $36,1 \%$ dan 28,4\%. Pada tahun 2007 pertumbuhan asset mengalami peningkatan menjadi $36,7 \%$. Namun pada tahun 2008 pertumbuhan asset mengalami penurunan lagi menjadi $31,3 \%$. Kemudian pada tahun 2009, 2010 dan 2011 pertumbuhan asset mengalami peningkatan lagi menjadi $33,4 \%, 47,6 \%$ dan $49,2 \%$. Namun pada tahun 2012, 2013 dan 2014 pertumbuhan asset mengalami penurunan lagi menjadi $34,1 \%, 24,2 \%$ dan $12,4 \%$.

Pertumbuhan

asset perbankan syariah mengalami fluktuasi dari tahun 2000 s.d. 2014. Pertumbuhan asset perbankan syariah terbesar terjadi pada tahun 2003 dengan pertumbuhan 101,5\%. Sedangkan pertumbuhan asset perbankan syariah yang paling kecil terjadi pada tahun 2014 dengan pertumbuhan 12,4\%. Walaupun demikian, pertumbuhan rata-rata asset perbankan syariah di Indonesia dari tahun $2000 \mathrm{~s} / \mathrm{d}$ 2014 mencapai $45 \%$ per tahun.

Jika pencapaian asset Bank Umum Syariah di Indonesia pada akhir tahun 2014 sejumlah Rp. 272,343 triliun dibandingkan dengan pencapaian Bank Umum Konvensional di Indonesia pada akhir tahun 2014 sejumlah Rp. 5.615,150 triliun, maka diperoleh market share perbankan syariah di Indonesia pada akhir tahun 2014 masih berada di bawah 5\% yaitu hanya mencapai $4,63 \%$.

2. Pertumbuhan DPK

Pertumbuhan

DPK perbankan syariah Indonesia pada tahun 2001 mengalami 
peningkatan sebesar $75,5 \%$.

Namun pada tahun 2002 pertumbuhan DPK mengalami penurunan menjadi $61,6 \%$. Kemudian pada tahun 2003 dan 2004 pertumbuhan DPK mengalami peningkatan menjadi $102,5 \%$ dan $105,2 \%$. Namun pada tahun 2005 pertumbuhannya mengalami penurunan lagi menjadi $31,4 \%$. Kemudian pada tahun 2006 dan 2007 pertumbuhan DPK mengalami peningkatan lagi menjadi 33\% dan 35,6\%. Namun pada tahun 2008 pertumbuhan DPK mengalami penurunan lagi menjadi $28,3 \%$. Kemudian pada tahun 2009, 2010, dan 2011 pertumbuhan DPK mengalami peningkatan lagi menjadi $41,8 \%, 45,5 \%$ dan $51,8 \%$. Namun pada tahun 2012, 2013, dan 2014 pertumbuhan DPK selalu mengalami penurunan menjadi $27,8 \%, 24,4 \%$ dan $18,7 \%$. Pertumbuhan

DPK perbankan syariah Indonesia mengalami fluktuasi dari tahun 2000 s.d. 2014. Pertumbuhan DPK perbankan syariah terbesar terjadi pada tahun 2003 dan 2004 dengan pertumbuhan $102,5 \%$ dan $105,2 \%$. Sedangkan pertumbuhan DPK perbankan syariah yang paling kecil terjadi pada tahun 2014 dengan pertumbuhan $18,7 \%$. Walaupun demikian, pertumbuhan rata-rata DPK perbankan syariah di Indonesia dari tahun 2000 s.d. 2014 mencapai $48,8 \%$ per tahun.

3. Pertumbuhan PYD

Pada

tahun

2001

pertumbuhan PYD mengalami peningkatan sebesar $61,3 \%$. Namun pada tahun 2002 pertumbuhan PYD mengalami penurunan menjadi 59,9\%. Kemudian pada tahun 2003 dan 2004 pertumbuhan PYD mengalami peningkatan menjadi $74,6 \%$ dan $104,6 \%$. Namun pada tahun 2005 pertumbuhan PYD mengalami penurunan lagi menjadi $32,7 \%$. Kemudian pada tahun 2006 dan 2007 pertumbuhan PYD mengalami peningkatan lagi menjadi $34,2 \%$ dan $36,9 \%$. Namun pada tahun 2008 dan 2009 pertumbuhan PYD mengalami penurunan lagi menjadi $32,5 \%$ dan $30,6 \%$. Kemudian pada tahun 2010 dan 2011 pertumbuhan PYD perbankan syariah mengalami peningkatan lagi menjadi 36,7\% dan 50,6\%. Namun pada tahun 2012, 2013 dan 2014 pertumbuhan PYD selalu mengalami penurunan menjadi $43,7 \%, 24,8 \%$ dan $8,3 \%$.

$$
\text { Pertumbuhan }
$$

PYD

perbankan syariah Indonesia juga mengalami fluktuasi dari tahun 2000 s.d. 2014. Pertumbuhan PYD perbankan syariah terbesar terjadi pada tahun 2004 dengan pertumbuhan $104,6 \%$. Sedangkan pertumbuhan asset perbankan syariah yang paling kecil terjadi pada tahun 2014 dengan pertumbuhan 8,3\%. Walaupun demikian, pertumbuhan rata-rata asset perbankan syariah di Indonesia dari tahun 2000 s.d. 2014 mencapai 45,2\% per tahun.

Perkembangan praktik perbankan syariah dari berbagai aspeknya telah menunjukkan catatan 
pertumbuhan, baik dari sisi jumlah asset, DPK dan PYD cukup menggembirakan. Pertumbuhan perbankan syariah di Indonesia jika dilihat dari sisi asset, DPK dan PYD, maka pertumbuhan yang paling besar terjadi pada tahun 2003 dan 2004 dengan pertumbuhan di atas $100 \%$. Namun posisi asset perbankan syariah pada akhir tahun 2011 telah mencapai Rp 145,467 triliun. Dengan posisi itu, pada tahun 2011 perbankan syariah Indonesia menduduki posisi keempat di dunia setelah Iran, Malaysia, dan Arab Saudi (Halim Alamsyah, makalah yang disampaikan pada Milad ke-8 IAEI: 2012). Namun pada tiga tahun terakhir dari sekarang pertumbuhan asset, DPK dan PYD selalu mengalami penurunan.

$$
\text { Selaku regulator, Bank }
$$
Indonesia yang telah dialihkan ke Otoritas Jasa Keuangan (OJK) pada tahun 2014, telah memberikan perhatian yang serius dan bersungguh-sungguh dalam mendorong perkembangan perbankan syariah. Semangat ini dilandasi oleh keyakinan bahwa perbankan syariah akan membawa 'maslahat' bagi peningkatan ekonomi dan pemerataan kesejahteraan masyarakat. Pertama, bank syariah lebih dekat dengan sektor riil karena produk yang ditawarkan, khususnya dalam pembiayaan, senantiasa menggunakan underlying transaksi di sektor riil sehingga dampaknya lebih nyata dalam mendorong pertumbuhan ekonomi. Kedua, tidak terdapat produkproduk yang bersifat spekulatif (gharar) sehingga mempunyai daya tahan yang kuat dan teruji ketangguhannya dari direct hit krisis keuangan global. Secara makro, perbankan syariah dapat memberikan daya dukung terhadap terciptanya stabilitas sistem keuangan dan perekonomian nasional. Ketiga, sistem bagi hasil (profit and loss sharing) yang menjadi ruh perbankan syariah akan membawa manfaat yang lebih adil bagi semua pihak, baik bagi pemilik dana selaku deposan, pengusaha selaku debitur maupun pihak bank selaku pengelola dana.

Selain itu ada juga beberapa faktor pendukung dan beberapa tantangan yang dihadapi dalam mengembangkan perbankan syariah di Indonesia, diantaranya adalah sebagai berikut: (Halim Alamsyah, makalah yang disampaikan pada Milad ke-8 IAEI: 2012)

1. Faktor pendukung perkembangan perbankan syariah.

Terdapat beberapa faktor yang secara signifikan menjadi pendorong peningkatan kinerja industri perbankan syariah, baik dalam kegiatan penghimpunan dana maupun penyaluran pembiayaan.

a. Ekspansi jaringan kantor perbankan syariah mengingat kedekatan kantor dan kemudahan akses menjadi salah satu faktor yang mempengaruhi pilihan nasabah dalam membuka rekening di bank syariah.

b. Gencarnya program edukasi dan sosialisasi kepada masyarakat mengenai produk dan layanan perbankan syariah 
semakin meningkatkan
kesadaran dan minat

masyarakat.

c. Upaya peningkatan kualitas layanan (service excellent) perbankan syariah agar dapat disejajarkan dengan layanan perbankan konvensional. Salah satunya adalah pemanfaatan akses teknologi informasi, seperti layanan Anjungan Tunai Mandiri (ATM), mobile banking maupun internet banking. Untuk mendukung hal ini, secara khusus Bank Indonesia mendorong bank konvensional yang menjadi induk bank syariah agar mendorong pengembangan jaringan teknologi informasi bagi BUS dan UUS yang menjadi anak usahanya.

d. Pengesahan beberapa produk perundangan yang memberikan kepastian hukum dan meningkatkan aktivitas pasar keuangan syariah, seperti: (i) UU No. 21 tahun 2008 tentang Perbankan Syariah; (ii) UU No. 19 tahun 2008 tentang Surat Berharga Syariah Negara (sukuk); dan (iii) UU No. 42 tahun 2009 tentang Amandemen Ketiga UU No. 8 tahun 1983 tentang PPN Barang dan Jasa. Lahirnya UU Perbankan Syariah mendorong peningkatan jumlah BUS dari sebanyak 5 BUS menjadi 11 BUS dalam kurun waktu kurang dari dua tahun (2009-2010).

Sementara penerbitan sukuk oleh pemerintah sebagai implementasi dari UU Sukuk menambah outlet penempatan dana perbankan syariah dalam rangka pengelolaan likuiditas. Sedangkan pemberlakukan UU No. 42 tahun 2009 merupakan 'tax neutrality' atas transaksi murabahah yang dilakukan oleh perbankan syariah di mana sebelumnya dikenakan pajak dua kali (double tax). Perlakuan pajak tersebut sangat merugikan perbankan syariah karena membuat pembiayaan dengan akad murabahah menjadi lebih mahal, sementara pembiayaan murabahah mempunyai porsi yang dominan dengan rata-rata $56,8 \%$ dalam lima tahun terakhir.

2. Tantangan pengembangan perbankan syariah

Di tengah perkembangan industri perbankan syariah yang pesat tersebut, perlu disadari masih adanya beberapa tantangan yang harus diselesaikan agar perbankan syariah dapat meningkatkan kualitas pertumbuhannya dan mempertahankan akselerasinya secara berkesinambungan. Tantangan yang harus diselesaikan perbankan syariah di Indonesia antara lain sebagai berikut: (Halim Alamsyah, makalah yang disampaikan pada Milad ke-8 IAEI: 2012)

a. Pemenuhan gap sumber daya insani (SDI), baik secara kuantitas maupun kualitas. Ekspansi perbankan syariah yang tinggi ternyata tidak 
diikuti oleh penyediaan SDI secara memadai sehingga secara akumulasi diperkirakan menimbulkan gap mencapai 20.000 orang. Hal ini dikarenakan masih sedikitnya lembaga pendidikan (khususnya perguruan tinggi) yang membuka program studi keuangan syariah. Selain itu, kurikulum pendidikan maupun materi pelatihan di bidang keuangan syariah juga belum terstandarisasi dengan baik untuk mempertahankan kualitas lulusannya. Untuk mengatasi

kesenjangan tersebut, diperlukan suatu terobosan, yang mungkin dapat dilakukan oleh lembaga-lembaga pendidikan dan perguruan tinggi yang dapat mengahasilkan SDI dalam jumlah yang besar (Amir Machmud dan Rukmana, 2010: 63). Dengan kata lain hal tersebut merupakan dukungan kalangan akademis termasuk Kementrian Pendidikan untuk mendorong pembukaan program studi keuangan syariah. Industri perbankan syariah secara bersama-sama juga dapat melakukan penelitian untuk mengidentifikasi jenis keahlian yang dibutuhkan sehingga dapat dilakukan 'link and match' dengan dunia pendidikan.

b. Inovasi pengembangan produk dan layanan perbankan syariah yang kompetitif dan berbasis kekhususan kebutuhan masyarakat. Kompetisi di industri perbankan sudah sangat ketat sehingga bank syariah tidak dapat lagi sekedar mengandalkan produk-produk standar untuk menarik nasabah. Pengembangan produk dan layanan perbankan syariah tidak boleh hanya sekedar 'mengimitasi' produk perbankan konvensional. Bank syariah harus berinovasi untuk menciptakan produk dan layanan yang mengedepankan uniqueness dari prinsip syariah dan kebutuhan nyata dari masyarakat. Namun disadari bahwa lifecycle dari suatu inovasi produk dan layanan perbankan syariah sangat pendek karena dengan mudah dan segera dapat ditiru oleh bank-bank lainnya sehingga mengurangi minat bank untuk berinovasi.

Untuk itu, perlu dibentuk semacam working group yang beranggotakan praktisi perbankan syariah untuk memikirkan secara bersamasama inovasi produk yang dapat dikembangkan. Mekanisme lain yang dapat diambil untuk mendorong inovasi produk dan layanan adalah memberikan patent selama beberapa tahun agar tidak ditiru oleh bank yang lain.

c. Kelangsungan program sosialisasi dan edukasi kepada masyarakat. Kegiatan untuk menggugah ketertarikan dan 
minat masyarakat untuk memanfaatkan produk dan layanan perbankan syariah harus terus dilakukan. Namun disadari bahwa kegiatan ini merupakan cost center bagi bank syariah. Selama ini kegiatan sosialisasi dan edukasi perbankan syariah didukung oleh Bank Indonesia melalui program 'iB Campaign' baik melalui media masa (iklan layanan masyarakat), syariah expo, penyelenggaraan workshop/seminar, dsb. Peran Bank Indonesia dalam hal ini akan berkurang seiring dengan pengalihan kewenangan pengaturan dan pengawasan sektor perbankan (termasuk perbankan syariah) kepada Otoritas Jasa Keuangan (OJK). Untuk itu, industri perbankan syariah perlu meningkatkan 'kemandirian', baik dalam hal formulasi program maupun pembiayaannya sehingga program ' $i B$ Campaign' dapat terus berlangsung secara berkelanjutan.

\section{PENUTUP}

Perkembangan praktik perbankan syariah di Indonesia dari berbagai aspeknya telah menunjukkan catatan pertumbuhan, baik dari sisi jumlah Bank Umum Syariah, jumlah Unit Usaha Syariah, jumlah BPRS beserta dengan jaringan kantornya, jumlah DPK dan jumlah pembiayaan yang disalurkan, serta jumlah asset yang cukup menggembirakan. Namun perkembangan tersebut tidak luput dari berbagai faktor pendukung dan tantangan di atas.

Hal itu menunjukkan bahwa upaya keras dari seluruh stake holders industri keuangan syariah sangat dibutuhkan untuk mendukung perkembangan bank syariah di Indonesia. Perlu keterpaduan langkah dari para praktisi, akademisi maupun asosiasi agar pengembangan menjadi lebih efektif. Untuk itu, peran semua pihak, baik pemerintah, ulama, IAEI, akademisi, dan masyarakat dalam mempelopori dan mendorong keterpaduan langkah untuk menjawab berbagai tantangan tersebut sangat diperlukan sehingga industri keuangan syariah nasional semakin berkualitas, berkembang secara berkelanjutan dan mampu bersaing dalam kancah persaingan global, khususnya dalam menyambut MEA 2015.

\section{DAFTAR KEPUSTAKAAN}

Adiwarman A. Karim. 2007. Bank Islam Analisis Figh dan Keuangan, Jakarta: PT. Raja Grafindo Persada.

Amir Machmud dan Rukmana. 2010. Bank Syariah: Teori, Kebijakan dan Studi Empiris di Indonesia, Jakarta: Erlangga.

Andri Soemitra. 2009. Bank dan Lembaga Keuangan Syariah, Jakarta: Kencana.

Frianto Pandia. 2005. "Lembaga Keuangan", Jakarta: PT. Rineka Cipta. 
Halim Alamsyah (Deputi Gubernur BI), "Perkembangan dan Prospek Perbankan Syariah Indonesia : Tantangan dalam Menyongsong MEA 2015", (Makalah yang disampaikan pada Milad ke-8 IAEI, 2012)

Heri Sudarsono. 2007. Bank dan Lembaga Keuangan Syariah, Yogyakarta: Ekonisia.

http://www.ojk.go.id, Statistik Perbankan Syariah tahun 2014

http:/ / www.pelita.or.id, Agustianto, Perkembangan dan Proyeksi Bank Syariah 2009

Iman Hilman, dkk., 2003. Perbankan Syariah Masa Depan, Jakarta: Senayan Abadi Publishing.

M. Ridwan. 2004. Manajemen Baitul maal wa Tamwil (BMT), Yogyakarta: UII Press.

M. Syafi'i Antonio. 1999. Bank Syariah Suatu Pengenalan Umum, Jakarta: Gema Insani

Sutan Remy Syahdeini. 2014. Perbankan Syariah: Produkproduk dan Aspek Hukumnya, Jakarta : Kencana.

Syukri Iska. 2012. Sistem Perbankan Syariah di Indonesia dalam Perspektif Fikih Ekonomi, Yogyakarta : Fajar Media Press.

Undang-undang Nomor 21 tahun 2008 tentang Perbankan Syariah. 